\title{
Emigration from Two Labor Frontier Nations: A Comparison of Moroccans in Spain and Mexicans in the United States
}

\author{
Douglas S. Massey \\ Princeton University. Sociology Department \\ dmassey@princeton.edu
}

\section{Philip Connor}

Pew Research Center. Pew Forum on Religion and Public Life

pconnor@pewforum.org

\section{Jorge Durand}

Universidad de Guadalajara. Departamento de Estudios Sobre Movimientos Sociales jdurand@princeton.edu

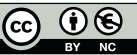

Received: 14-10-2010

Accepted: 27-05-2011

\begin{abstract}
Mexico and Morocco share many common characteristics as labor migrant pools for industrialized countries to the North. However, comparisons between migrants from each country are few, particularly with respect to economic outcomes using nationally representative data. Using recent immigrant surveys from Spain and the United States, this paper presents the first quantitative analysis to compare Moroccans and Mexicans, testing for the effects of human and social capital on employment, occupational attainment, and wages. Although the lower employment levels of Moroccans compared to Mexicans would seem to suggest greater labor market discrimination against Moroccans in Spain, closer inspection of the returns to various forms of capital and other inputs yields a more mixed picture. Both methodological and social explanations for these mixed findings are discussed.
\end{abstract}

Key words: immigration; foreign workers; Morocco; Mexico; human resources; social capital; comparative analysis; ethnosurvey questionnaire.

Resumen. La emigración laboral a través de dos fronteras nacionales: una comparación entre los marroquies en España y los mexicanos en Estados Unidos

México y Marruecos comparten muchas características comunes, como la de ser países que exportan mano de obra a los vecinos países industrializados del norte. Sin embargo, los estudios comparativos entre los flujos migratorios de ambos son pocos, y menos aún lo son aquellos que utilizan a escala nacional datos representativos sobre resultados económicos. A través de la utilización de estudios recientes de España y EEUU, este artículo presenta el primer análisis cuantitativo que compara marroquíes y mexicanos, con el fin de indagar 
los efectos del capital social y humano en el empleo, en el logro profesional y los salarios. Aunque la ocupación en los puestos de trabajo menos cualificados de los marroquíes en España, en comparación con los mexicanos en EEUU, podría parecer sugerir una mayor discriminación en el mercado laboral de los primeros, al inspeccionar el retorno de varias formas de capital y otros inputs, se infiere una explicación algo más compleja. Tanto la explicación metodológica como la social, serán ampliamente discutidas aquí.

Palabras clave: inmigración; trabajadores extranjeros; Marruecos; México; recursos humanos; capital social; análisis comparativo; etnoencuesta.

\section{Summary}

1. Similarities and Differences Between the Two Streams

2. Sources of Data

3. Socio-demographic Characteristics of Moroccans and Mexicans

4. Determinants of Employement
5. Occupational Attainement in Spain and the United States

6. Wage Determination in Binational Perspective

7. Summary and Conclusion

References

Mexico and Morocco are examples of what Skeldon (1997) calls "labor frontier nations", middle income states whose economic and infrastructural development has advanced sufficiently to loosen bonds to local people and institutions but not enough to provide full employment and other economic opportunities, thereby increasing both internal and international migration to nearby developed nations. The overwhelming majority of migrants who leave Mexico, for example, go to the United States (Massey, Durand, and Malone 2002), with the number peaking during the 1990s (Massey, Durand, and Pren 2009), though in recent decades a small movement of labor migrants to Canada has also emerged (Basok 2002, 2003; Hennebry 2008).

Morocco likewise has a long history of migration to neighboring countries in Europe, dating back to 1912 when the French-Spanish Protectorate was established in what is now Morocco, leading to the active recruitment of Moroccans to European destinations. In contrast to the case of Mexico, however, Moroccans early on began migrating to multiple destinations (de Haas 2005a; Reniers 1991). Although initial movements were mainly to Algeria and through Algeria (a département of France until 1963) to the heartland of France, Moroccan emigration diversified into other European destinations during the period of guest worker recruitment in the 1960s. Following the recognition of its independence in 1956, Morocco's leaders signed temporary worker agreements with West Germany and France in 1963, Belgium in 1964, and the Netherlands in 1969 (de Haas 2007).

After guest worker recruitment ended in 1973, emigration from Morocco during the 1970s mainly involved women and children moving for purposes of family reunification, though labor migration to oil-exporting nations did 
begin at this time. During the 1980s, unskilled labor migrants increasingly went to Italy and Spain, while skilled migrants migrated in smaller numbers to the Gulf Region as well as to Canada, the United States, and Britain (de Haas 2007). Although more Moroccan migrants currently live in France than in Spain, migration to the latter has grown more rapidly in recent years. Whereas the Moroccan population of France grew by $57 \%$ between 1990 and 2005, that of Spain increased by $673 \%$ (de Haas 2005b). As of 2005, some 424,000 migrants had registered with Moroccan consulates in Spain and 397,000 had registered with Spanish authorities (de Haas 2007). By 2007 the latter figure had grown to more than 575,000 persons (United Nations 2009).

At present, Moroccans constitute around $12 \%$ of all foreigners living in Spain, while Mexicans comprise around a third of all immigrants living in the United States. The rising tide of Moroccan migration to Spain has attracted the attention of scholars and led to a burgeoning research literature (see Roque 1994; Bodega et al. 1995; White 2001; Salih 2001; Soriano Miras 2006; de Haas and Fokkema 2009). Mexican immigration to the United States has long attracted the attention of scholars, and over the years has produced a huge research literature (for reviews, see Durand and Massey 1992; Massey et al. 1994; and Donato et al. 2010).

Although similarities and differences between the two flows lend themselves to interesting comparisons, few studies to date have considered Mexican and Moroccan migration from a comparative perspective. The existing comparative work has generally been based on small, localized samples (Kopinak and Soriano Miras 2009) and has typically focused on issues of identity and transnationalism, particularly as they have played out among women (Relaño Pastor and Soriano Miras 2006; Soriano Miras 2008). To our knowledge, researchers have yet to examine patterns and processes of labor market integration using nationally representative data. Here we draw upon two newly available surveys to undertake such an analysis. We begin this article by outlining similarities and differences between Morocco and Mexico as sending nations and highlight contrasts between Spain and the United States as receiving nations. After describing the strengths and weaknesses of our two data sources and their points of comparability and difference, we move on to estimate multivariate models of employment, occupational attainment, and earnings for immigrants as a whole and for males and females separately.

\section{Similarities and Differences Between the Two Streams}

Morocco and Mexico offer analysts an interesting set of similarities and differences for comparative study. In terms of similarities, both countries are "frontline states" separated from developed nations by thin water and land borders. Until Algerian independence in 1963, the Moroccan-Algerian frontier itself constituted a nearly 2,000-kilometer land border with Europe. Since then the land border with Europe has been reduced to the fortified perimeters around the Spanish enclave cities of Ceuta and Melilla, totaling around 19 
kilometers. Although the entire coastline of Morocco in a sense constitutes a water border with Europe, the two critical points are the 14 kilometer long Strait of Gibraltar separating Morocco from Spain, and the 100 kilometer span of Atlantic Ocean separating it from the Canary Islands. In the case of Mexico, the 3,000 kilometer border is about evenly composed of the Rio Grande River, which forms the southern border of Texas, and the treaty line that forms the southern boundary for the states of New Mexico, Arizona, and California. The United States and Spain represent the only two contemporary cases where walls have been specifically built to keep people out.

Given their common proximity to the developed world, emigration from both countries has been massive and around 10\% of Moroccan and Mexican nationals currently reside abroad (de Haas 2007; Massey 2010). In both nations, emigration is motivated not so much by a lack of economic development as by structural transformations accompanying market expansion and global integration (Massey 1988; White 1999). In both cases emigration takes place against a historical backdrop of colonization and conquest (Massey, Durand and Malone 2002; de Haas 2007). Both Spain and the United States, have also mounted intensive enforcement campaigns, and in the face of restrictions a large number of those who depart each country do so as undocumented migrants (Migration News 1998; Singer and Massey 1998). Although unauthorized migrants often later convert to legal status in both countries, regularization programs have been more frequent and comprehensive in Spain than in the United States (Durand, Massey, and Parrado 1999; Arango and Jachimowicz 2005). As a result, a larger share of Mexicans in the United States languish in a status of undocumented immigrants compared with Moroccans in Spain (Lopez 2007; Massey, Durand, and Pren 2009). Nonetheless, both Moroccans in Spain and Mexicans in the United States have been subject to ideological campaigns portraying them as threatening "others" (Roque 1994; Calavita 1998; Massey 2008).

Despite the many similarities between Mexico and Morocco, there are also several key differences. First, Morocco is much poorer than Mexico in both relative and absolute terms. Whereas Morocco's GDP per capita of $\$ 4,500$ is just 13\% of Spain's $(\$ 34,600)$, Mexico's per capita GDP of $\$ 14,300$ is $30 \%$ of the U.S. GDP $(\$ 47,500) .{ }^{1}$ Second, in addition to being economically more distant from Spain, Moroccan migrants are also more culturally distinct than Mexicans are from the United States. Both Mexico and the United States are multiracial settler societies colonized by Christian powers from Europe. Although Mexico's Spanish Catholic culture may once have been quite distinct from the Anglo-Saxon Protestant culture of the United States, these differences have waned over the years as the United States has become more Catholic and denominational boundaries have blurred (Alba 2005). At the same time, Mexico has become more secular, and more Americanized since the arrival of the North American Free Trade Agreement in 1994.

1. All figures have been adjusted for purchasing power parity (U.S. Central Intelligence Agency 2009). 
Both Mexico and the United States continue to be overwhelmingly Christian in terms of religious belief and practice, western in culture, and democratic in political orientation (though Mexico is a more recent arrival to full democracy). By contrast, Morocco is overwhelmingly Muslim in religion, Arabic in culture, and monarchical in political structure. Moreover, given the rise of militant Islam directed at Europe, Spain's unique status as a former Muslim territory, and the actual occurrence of Muslim terrorist attacks in Madrid during March of 2004, one might expect hostility to be more pronounced against Moroccans in Spain than Mexicans in the United States, and the barriers to economic integration that much higher.

There are, however, a variety of mitigating circumstances working against Mexican immigrants to level the playing field and leave the question of which group experiences more barriers and more discrimination very much open. Perhaps, the most glaring difference is the larger role that illegality plays among Mexicans in the United States. As of 2008, around 60\% of all Mexicans present in the United States lacked legal documents (Massey 2010) and among legal immigrants two-thirds had prior illegal experience (Massey and Malone 2003). By contrast, among Moroccans interviewed by the Encuesta Nacional de Inmigrantes, only 7\% were unauthorized at the time of the survey, a low figure that reflects Spain's regular implementation of amnesty and legalization programs in recent years (Lopez 2007). ${ }^{2}$

The prevalence of undocumented immigrants opened the door to a broad political mobilization against Mexican nationals that framed them as illegal criminals, threats to national security and, since 9/11, terrorists (Massey, Durand, and Malone 2002; Massey 2009, 2010). The active demonization of Mexican immigrants has, in turn, led to record levels of anti-immigrant repression at the border and within the United States (Massey, Durand, and Pren 2009) as well as to rising discrimination against Latinos of all origins (Massey 2010). As a result of the rising tide of anti-immigrant hostility, one recent study found that the more time Latinos spend in the United States, the less likely they are to identify themselves as "Americans" (Massey and Sánchez 2010).

Historically, discrimination against Mexicans is nothing new; but in earlier years a simple way to escape repression north of the border was to head southward. A common practice was to use temporary labor in the United States as a strategic resource for mobility at home by migrating sporadically over the life course to earn money for specific social and economic projects before returning to the home community (Massey et al. 1987). With the militarization of the Mexico-U.S. border during the 1990s, however, this strategy of recurrent migration became more costly and less tractable, and rates of return migration plummeted to very low levels (Massey, Durand, and Malone 2002; Massey, Durand, and Pren 2009). By contrast, Moroccan migrants in Spain appear to

2. To maintain a consistently legal population for both surveys in the United States and Spain, the currently undocumented Moroccan migrants in Spain were removed from the sample. 
be moving away from long-term settlement toward a pattern of seasonal repeat migration labeled "pendulum migration" in the European literature (de Haas and Fokkema 2009).

Given these complications, it is not at all clear which group is likely to suffer the greatest challenges to economic advancement in the host country - Moroccans in Spain or Mexicans in the United States. Predictions become even more nebulous when one considers the influence of gender (Soriano Miras 2008; Kopinak and Soriano Miras 2009). Although both Mexico and Morocco are patriarchal cultures in which women defer to male authority, women in Latin America generally enjoy more autonomy, freedom, and independence than those in Morocco (Gregorio Gil and Ramírez Fernández 2000). Although female migrants from both countries may expect more opportunities for employment and earnings in the receiving society, thereby increasing their status and bargaining position within the household, the effect on status is probably larger for Moroccans than Mexicans because the patriarchal constraints on Moroccan women are more prominent.

\section{Sources of Data}

Given this complex set of similarities and differences between the two cases, we approach the comparative analysis of Mexican migration to the United States and Moroccan migration to Spain with a series of empirical questions rather than a set of definitive hypotheses. Our data are based on two nationally representative surveys of immigrants conducted in 2003 (in the United States) and 2007 (in Spain). Although both surveys are representative probability samples, the target populations are quite different. The Encuesta Nacional de Inmigrantes (ENI) was conducted by Spain's National Statistical Institute and was designed to represent all foreign-born persons aged 16 or over who lived in family households during the period from November 2006 to February 2007. Respondents had to reside in Spain for at least one year and intend to remain there for at least one year more. The sampling frame was the municipal household registry, a nationwide registration system that includes all noninstitutional dwellings in the country and registers all persons living within those dwellings for purposes of providing basic services. Since registration is required and tied to services and the registry has not previously been used for immigration enforcement, the ENI sample is generally thought to offer relatively complete coverage of the immigrant population, both documented and undocumented. The ENI survey carried out in-person interviews with some 15,465 persons, of whom some 1,545 (995 labor market participants) were born in Morocco. Respondents had the choice of responding to the survey in Arabic or Spanish.

By Contrast, the United States' New Immigrant Survey (NIS) was conducted by a team of researchers based at three private universities (Princeton, Yale, and New York University) and the RAND Corporation, with the project being funded by a consortium of U.S. federal agencies (including the National 
Institute of Child Health and Human Development, the National Institute on Aging, the National Science Foundation, the Immigration and Naturalization Service, the Bureau of Citizen and Immigrant Services, and the Department of Health and Human Services) along with Pew Charitable Trusts. The NIS is a stratified probability sample of the entering cohort of immigrants who received permanent residence documents from May to November 2003 (Jasso, Massey, Rosenzweig, and Smith forthcoming). They were randomly selected from monthly lists of immigrants who had just received residence visas by the Bureau of Citizen and Immigrant Services. A face-to-face or a telephone interview was conducted within six months of visa issuance, yielding a sample of 8,573 households surveyed with a response rate of $68 \%, 1,164$ of whom (731 labor market participants) were born in Mexico. Respondents were interviewed in whichever language they preferred, Spanish or English.

Thus, whereas the ENI is a national sample of the entire immigrant population residing in Spain at the time of the survey, the NIS is a national sample of a single cohort of immigrants who became legal residents during the study period. Given that the NIS consists of newly documented legal immigrants whereas the ENI includes all current residents, one might expect the U.S. sample to be skewed toward less experienced immigrants compared with the Spanish sample, but as we shall see actual differences are not that large because most "new" legal immigrants to the United States have already spent time in the country in one status or another.

The two samples are thus quite different but nonetheless similar in many respects. Although the ENI surveys Spain's entire immigrant population in 2007 and the NIS surveys the cohort of legal immigrants to the United States in 2003, both offer accurate representations of their target populations based on robust sampling designs. Each survey is multi-cohort in the sense that some respondents have lived in the destination country for many years while others have only come recently. The sample size is sufficiently large in both cases to enable detailed statistical estimation, and both surveys include formerly undocumented as well as currently documented migrants.

\section{Socio-demographic Characteristics of Moroccans and Mexicans}

Table 1 displays means for Mexicans in the United States and Moroccans in Spain who are in the labor market (employed or unemployed and searching for work). We test systematically for statistical differences between the two groups, including differences between the two migrant groups as a whole and for men and women separately. In terms of economic outcomes, Mexicans and Moroccans differ sharply, at least on the surface. In the overall sample, the rate of employment is lower among Moroccans $(77 \%)$ than Mexicans $(83 \%)^{3}$, and

3. Those who indicated they were employed were coded as one with all others coded zero. A few cases were added to those who were employed if they indicated they were not employed yet later stated they worked on average 35 hours a week or more. 
the average hourly wage in PPP dollars is considerably lower for Moroccans $(\$ 5.77)$ than for Mexicans (\$10.91). ${ }^{4}$ The minimum wage in Spain is 624 Euros per month, whereas the current minimum wage of $\$ 7.25$ per hour works out to $\$ 1,160$ per month for a full time worker. It should be noted, however, that there is little difference in the share of skilled migrants among Mexican workers in the United States compared with Moroccan workers in Spain.

Considering economic outcomes by gender tells a similar story, except that the wage gap is larger among men and the employment differential larger among women. Whereas Mexican men in the United States averaged \$12.41 per hour in earnings, Moroccan men in Spain earned half as much at \$5.92 per hour; and whereas $77 \%$ of Mexican women were employed in the United States, only 65\% of Moroccan women held jobs in Spain. The difference in the share holding a skilled occupation remains insignificant for men and women when estimated separately. ${ }^{5}$

Although it appears that Moroccans in Spain earn less than Mexicans in the United States, the means are not adjusted for duration of time within the country or for within country differences. Also, Spain during the data collection period had a much higher unemployment rate $(9.2 \%$ in 2007) than the United States (6\% in 2003). Finally, given differences in currency exchange between 2007 and 2003, we would expect to observe some wage differences between the two countries. Nevertheless, at first glance it appears that Moroccans have a more difficult time integrating economically in Spain than Mexicans in the United States.

Turning to demographic characteristics of the two groups, we find both similarities and differences. Although average age is about the same for

4. Each survey measured financial compensation according to the respondent's preferred unit (i.e. hourly, weekly, monthly, or annually). We divided total salary by total hours for each pay unit to estimate the hourly wage. The ENI hourly wage was then converted to U.S. dollars based on the exchange rate on January 2, 2007, and then further converted to Purchasing Power Parity over GDP (PPP) 1.33 U.S. dollars equaled 1 Euro on January 2, 2007. Based on OECD estimates, PPP for Spain in 2007 was 0.741231 . The United States is 1 . To avoid negative logs for hourly wages, all hourly wages less than 1 were equalized to 1. None of these alterations affected the direction or statistical significance of the findings in this paper.

5. In the NIS, unskilled occupations include farming, fishing, forestry, construction, manufacturing, installation, food preparation, transportation, material moving workers, food preparations as service related, cleaning and building service, entertainment attendants, personal care and service workers, and sales workers. Skilled services/professional jobs include executive, administrative and managerial jobs, scientists, engineers, counselors, religious workers, teachers, legal personnel, entertainers, media workers, and health care workers. In the ENI, unskilled refers to workers in manufacturing, construction, mining, operational machinery, as well as restaurant, personal, protection, and commercial services workers. Professional/ skilled occupations include public administration, technicians, scientists, support professionals, and skilled workers in agriculture and fishing. We recognize that this classification grouping is not ideal given the occupational categories in each dataset; however, alternative jostling of original dataset categories within this grouped classification schema results in very similar findings. 


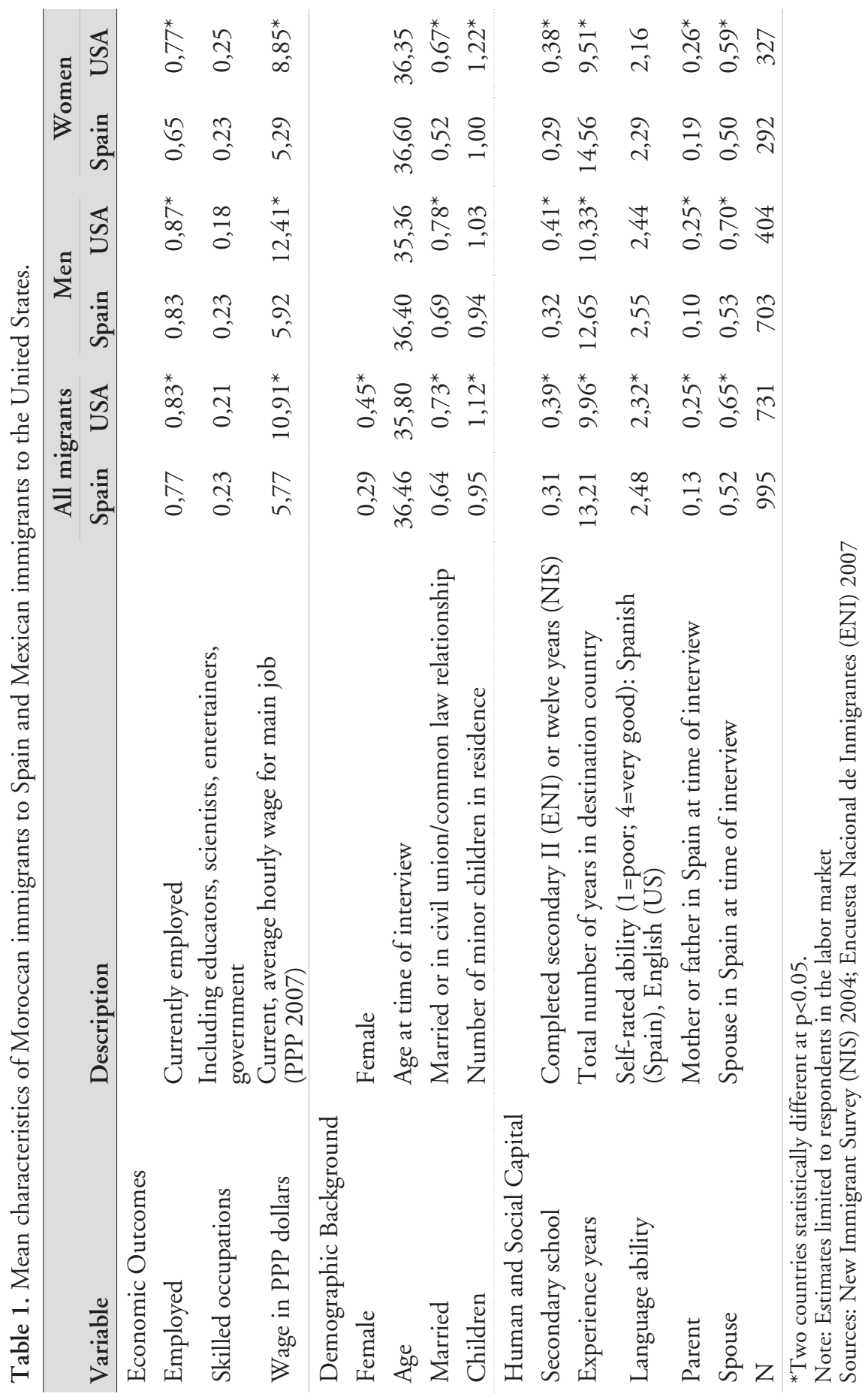


Moroccans and Mexicans when computed for the entire group or calculated separately for male and females, we observe a significantly smaller share of women among Moroccan migrants in Spain (29\%) than among Mexicans in the United States (45\%), consistent with the fact that the Morocco-to-Spain stream constitutes a more recent phenomenon. Mexicans are also more likely to be married (73\%, compared with 64\% for Moroccans) and more likely to have children (an average of 1.12, compared with 0.95 for Moroccans), suggesting that family migration is more common among Mexicans in the United States than among Moroccans in Spain. Indeed, looking at males and females separately we see that only $69 \%$ of Moroccan men and $52 \%$ of Moroccan women were married at the time of the survey, compared with $78 \%$ of Mexican men and $67 \%$ of Mexican women. In other words, despite patriarchal restrictions, almost half of Moroccan women in Spain appear to be migrating outside of marriage and the number of children present is thus lower for them (1.00) than for Mexican women in the United States (1.22), even though Total Fertility Rates in Morocco are higher $(\mathrm{TFR}=2.51)$ than in Mexico (TFR=2.34).

The two samples also vary considerably in terms of human capital. A larger proportion of Mexicans have completed secondary schooling, a pattern that is similar for both gender groups. However, what Moroccans lack in education compared to Mexicans, they gain in terms of years of experience. Whereas the average Moroccan had been in Spain 13.21 years, the average Mexican had been in the United States only 9.96 years. The differential in host country experience was particularly large among women, where Moroccans averaged 14.56 years compared with 9.51 years among Mexicans. The corresponding figures for male migrants were 12.65 years and 10.33 years. The differences in human capital end there, however. Proficiency in the host country language (English in the U.S. and Spanish in Spain) is quite small, albeit significant, in the full sample and insignificant when men and women are tested separately.

In terms of social capital, Mexicans are much more likely to have relatives present in the host country than Moroccans, indicating the maturity of the Mexican migration stream. Whereas $25 \%$ of Mexicans reported having a parent living in the United States, this was the case for only 13\% of Moroccans in Spain. Similarly, whereas 65\% of Mexicans were accompanied by a spouse, only $52 \%$ of Moroccans had a spouse present. ${ }^{6}$ Again this pattern is consistent with the recent emergence of Moroccan migration: in the early stages of labor migration, the typical migrant is a young, single male or a married male traveling alone seeking to earn money for family members who remain behind in the country of origin.

In sum, with respect to economic, demographic, and social characteristics we have found more differences than similarities in Moroccans in Spain compared with Mexicans in the United States, both in terms of outcome variables

6. Taking into account additional network ties (e.g. siblings) would be ideal in testing differences in social capital between the two host countries. Unfortunately, consistent operationalization of these ties across the two datasets was unavailable. 
(employment and wages) and predictors (gender, family situation, education, and years of experience). Of course, it remains to be seen how these differences play out in the labor markets of each country. In the next section we consider the determinants of employment within each group.

\section{Determinants of Employment}

Multivariate models allow us to evaluate more effectively differences in economic adaptation between Moroccans and Mexicans. By comparing coefficients for predictors of key economic outcomes, we can determine whether one group or another is adapting better or worse economically. The entry point for labor market integration is getting a job, and Table 2 shows unstandardized coefficients for a logit model of employment estimated using the variables in Table 1 as predictors. To account for possible clustering of responses owing to unobserved heterogeneity at the regional level, we used STATA's cluster command at the state level in the United States and at the provincial level in Spain. ${ }^{7}$ In terms of table presentation in this and the regression tables displayed below, the full sample estimates are in the far left columns whereas estimates by gender are to the right. Bold print coefficients indicate a significant difference between Moroccans in Spain and Mexicans in the United States.

Table 2 shows that females in both groups experience a significant employment penalty, though the likelihood of finding work is somewhat lower for Moroccan women $(b=-0.949)$ than Mexican women $(b=-0.713)$, ceteris paribus. The process of job attainment is thus quite different for men and women, justifying the estimation of separate models shown in the middle and righthand columns. Age has the expected curvilinear effect on employment for both Mexicans and Moroccans in the model estimated for all migrants, but we observe significant differences between the two groups in terms of returns to human and social capital. Whereas host country experience yields a significant increase in the odds of employment for Mexicans in the United States, it has no effect for Moroccans in Spain. Likewise, whereas the presence of a spouse increases the odds of employment significantly for Mexicans, it has no effect for Moroccans.

When models are estimated separately by gender, however, we see a more nuanced story emerge. Among men, we observe a significant return to secondary schooling among Mexicans but not Moroccans, and although host country experience is not significant in predicting the employment of either group, the effect of age (another measure of experience) is much larger for Mexicans than Moroccans. The odds of employment increase much more rapidly with rising age among Mexican men $(b=0.210)$ than among Moroccan men $(b=0.038)$, but it also falls off more rapidly as migrants move into late adulthood ( $b=-0.003$ for Mexicans; $b=-0.001$ for Moroccans). In general, the variables in

7. Direction and significance of results are similar without these robust standard errors. This clustering variable is employed in all regression analyses. 


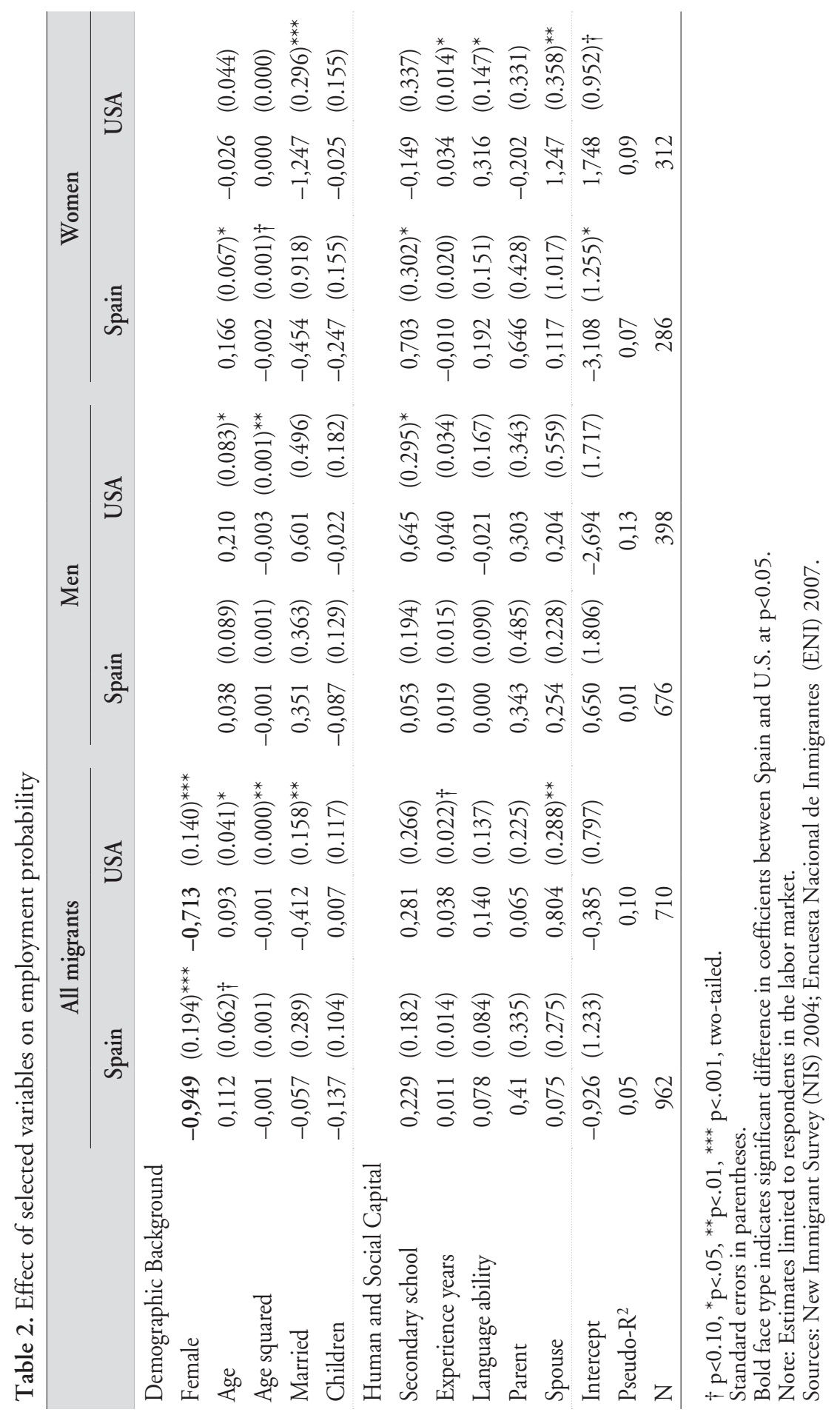


the model predict employment very poorly for Moroccans (pseudo $\mathrm{R}^{2}$ of 0.01 ) compared with Mexicans (pseudo $\mathrm{R}^{2}$ of 0.13 ).

Human and social capital appear to be more important in predicting the employment of women than of men, but again effects are stronger for Mexicans than Moroccans. Among Moroccan women, the completion of secondary school is positively associated with employment, raising the odds of finding a job by a factor of two $[\exp (0.703)=2.02]$. Likewise, age increases the odds of employment for Moroccan women in the early labor force ages $(b=0.166)$, but not for Mexican women $(b=-0.026)$. Whereas education and age have no effect on the employment of Mexican women, English language ability and years of experience have quite strong and significant effects. Raising English language ability by one point within a four-point scale raises the odds of female employment by $37 \%[\exp (0.316)=1.372]$ and each additional year of experience raises the odds by $3.5 \%[\exp (0.034)=1.035]$.

Marriage and presence of a spouse only affect the employment of Mexican women and not Moroccan women, but the effects are complex and depend on whether the spouse is in the country or not. The odds of employment are lowest for married women traveling without a spouse $[\exp (1.748-1.247)=1.65]$ and much higher both for single women $[\exp (1.748)=5.743]$ and for married women traveling with a husband $[\exp (1.748-1.247+1.247)=5.743]$. In general, the model predicts employment slightly better for Mexican women than Moroccan women (pseudo R-squared of 0.09 and 0.07, respectively).

In sum, the barriers to employment seem most pronounced for Moroccan men in Spain, for whom no demographic variable or indicator of human or social capital is significant in predicting the odds of finding employment. Moroccan women fare somewhat better, as their odds of employment increase with age and with education. Married Mexican women migrating with spouses fare even better: they are able to capitalize both on experience and language ability in finding employment. Although Mexican men do not capitalize on language ability and experience, they do experience significant returns from age and education, and their model displays the best fit overall.

\section{Occupational Attainment in Spain and the United States}

The procurement of employment is the first step on the road to economic integration, yet the achievement of higher occupational status over time is a better indicator of long-term economic adaptation. Table 3 presents unstandardized coefficients for a logit model predicting the likelihood of holding a skilled rather than an unskilled job. Among Mexicans in the United States, women are better able to advance occupationally than men, other things being equal, whereas among Moroccans we observe no gender differential. Mexican women are nearly two times more likely to hold a skilled job than Mexican men $[\exp (0.661)=$ 1.937]. Among Moroccans in Spain the major demographic contrast occurs with respect to marriage rather than gender: married migrants are about half as likely to attain a skilled occupation as unmarried migrants $[\exp (-0.676)=0.509]$. 
$\overleftarrow{s}$

छี

คี

$\overleftarrow{3}$

总

离

ก

อั

4

包

$\sum_{\Sigma}^{\Xi}$

कึ

离

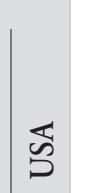

焉

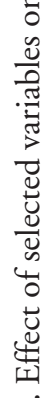

离

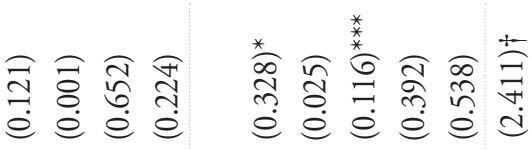

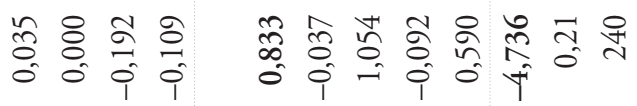

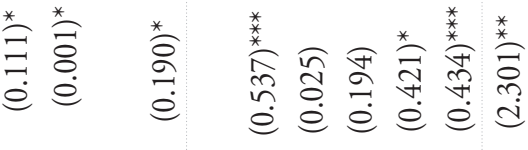

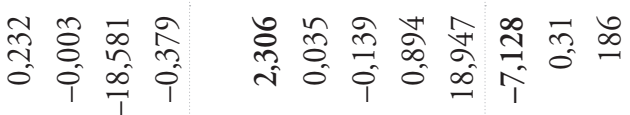

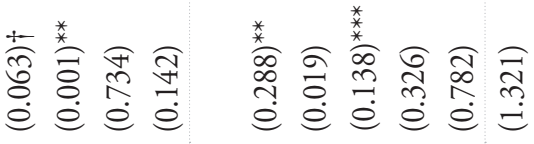

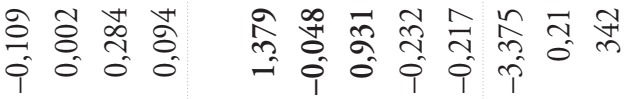

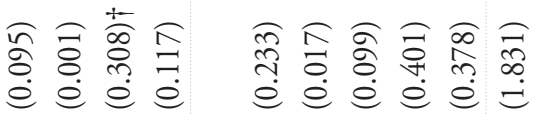

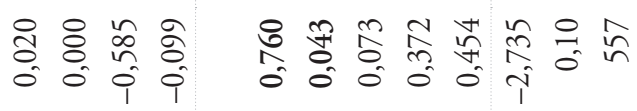

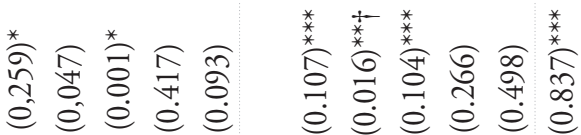

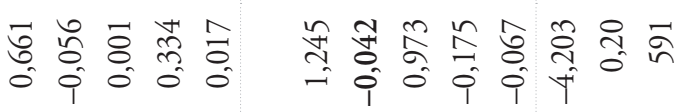

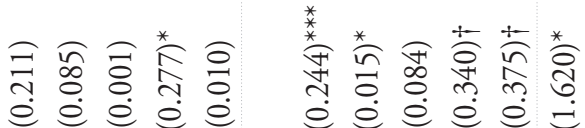

들 홍

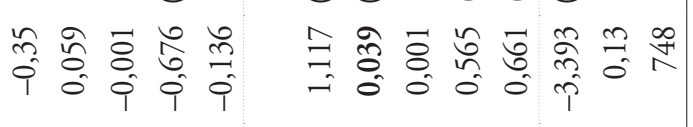

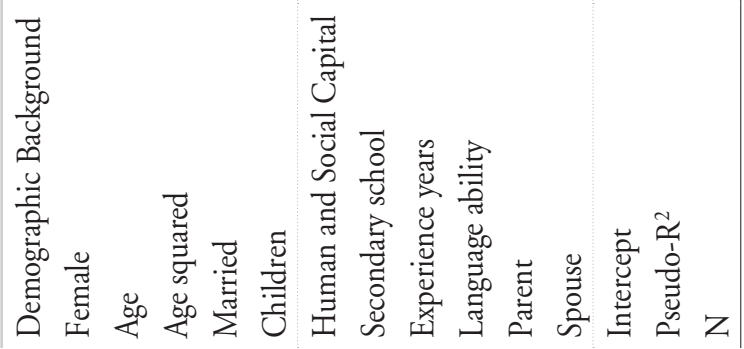

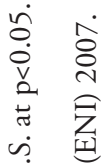

苞

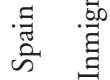

ปี

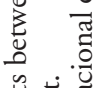

密离艺

氖苋

苟

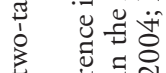

ह

高苞苞気

i

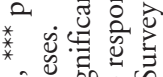
$\therefore-\frac{50}{2}$ क

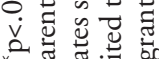

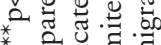
n.. 0.

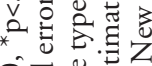
웠 0 西

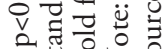


Moving on to consider the effect of human capital on occupational attainment, we find that the completion of secondary school is positively associated with having a skilled occupation among members of both groups. In both cases, secondary schooling more than triples the odds of attaining a skilled occupation $^{8}$. In terms of social capital, we observe modest positive effects for Moroccans, but no significant effects for Mexicans. Other things being equal, having a parent present in Spain increases the odds that a Moroccan migrant will hold a skilled occupation by $76 \%[\exp (0.565)=1.759]$ and having a spouse present increases the odds by $94 \%[\exp (0.661)=1.937]$.

We observe the strongest contrasts in the effects of host country experience and host country language ability. Among Mexicans, occupational advancement occurs mainly through language acquisition rather than experience per se. Whereas each unit of language ability increases the odds of achieving a skilled occupation by a factor $2.6[\exp (0.973)=2.646]$, the odds of holding a skilled job actually decline by $4 \%$ with each year spent in the United States $[1-\exp (-0.042)=.041]$. By contrast, among Moroccans the likelihood of attaining a skilled occupation rise by $4 \%$ with each year spent in Spain $[\exp (0.039)=0.040]$, but Spanish language ability has virtually no effect on occupational attainment $(b=0.001)$.

Among Moroccans, therefore, occupational attainment is achieved by accumulating time in Spain irrespective of language skills, but among Mexicans in the United States occupational attainment stems from English language ability alone. The more time a Mexican spends in the United States without learning English, the slimmer the chances of occupational advancement. When the models are estimated separately by gender, we observe that this contrast is only characteristic of men, however. In addition, when men are considered independently, the positive effect of education is significantly larger for Mexicans than Moroccans. Whereas secondary schooling raises the odds of skilled occupational attainment by a factor of four among Mexican men $[\exp (1.397)=4.043]$, it only doubles the odds of achieving a skilled occupation among Moroccan men $[\exp (0.760)=2.138]$. As before, the effect of host country experience is significantly positive in the case of Moroccans $(b=0.043)$ but significantly negative in the case of Mexicans $(b=-0.048)$.

The social capital effects observed for Moroccans in the overall model appear to be confined to females, though the estimates are somewhat unstable owing to the small number of cases. Although the coefficient associated with the presence of a spouse is huge, so is the effect of being married and the two largely offset one another. Nonetheless, having a parent present increases the odds that a Moroccan woman will hold a skilled occupation by a factor of $2.4[\exp (.894)=2.445]$. Among women, the key contrast between Moroccans and Mexicans concerns the influence of schooling and language ability. The effect of secondary schooling on occupational attainment is much larger for

8. $\quad[\exp (1.117)=3.056$ among Moroccans; $\exp (1.245)=3.473$ for Mexicans; the difference between them is not significant]. 


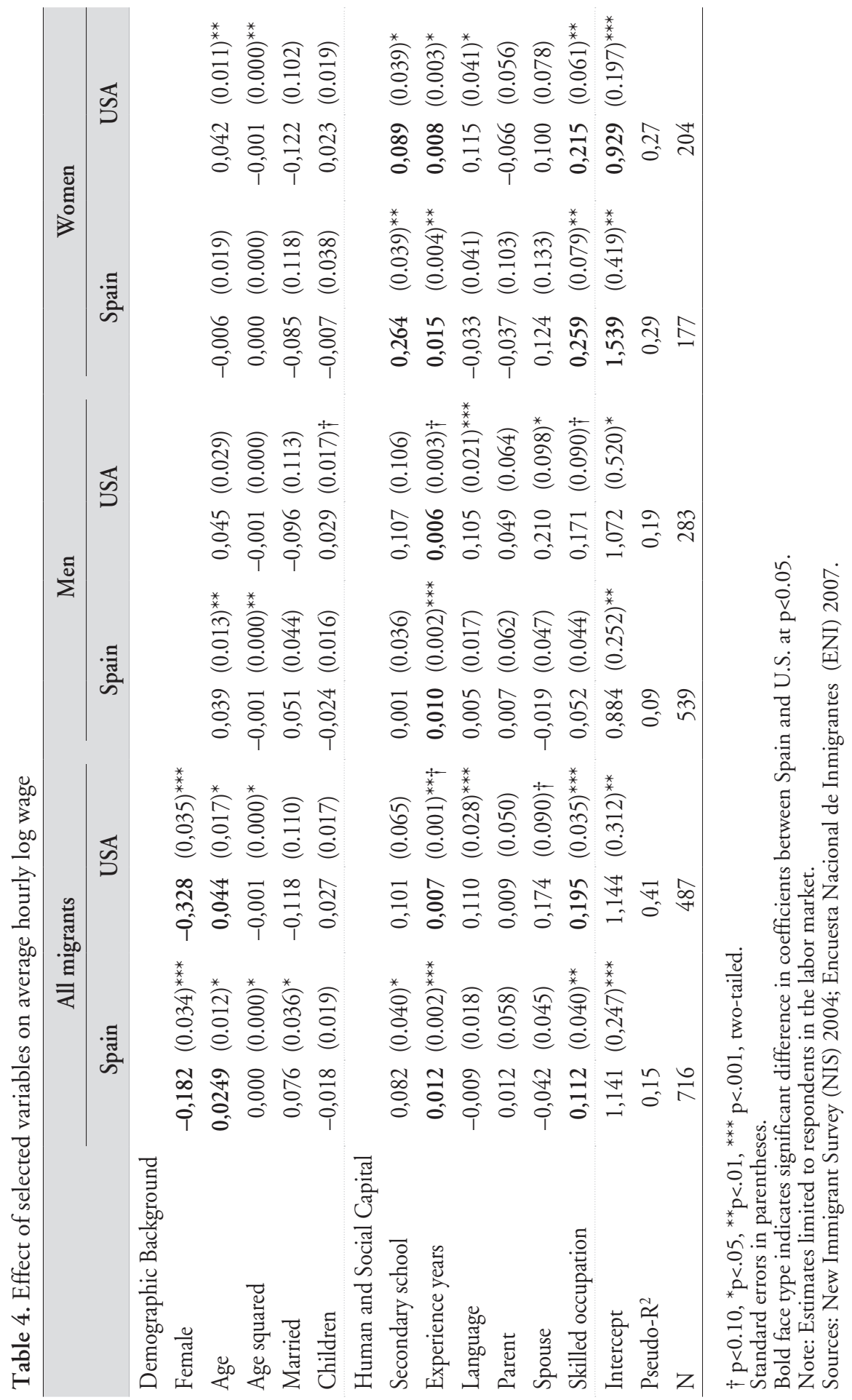


Moroccan women $(b=2.036)$ than for Mexican women $(b=0.833)$, whereas the effect of host country language ability is much larger for Mexican women $(b=1.054)$ than for Moroccan women $(b=-0.139)$.

We thus observe a rather complex and highly gendered contrast in the process of occupational achievement between Moroccans in Spain and Mexicans in the United States. Among males, occupational achievement is achieved by Moroccans through the accumulation of time in Spain and through the prior completion of secondary schooling, but not by mastery of Spanish. Occupational achievement by Mexican males is achieved through mastery of English and secondary schooling has an even larger effect. In the absence of schooling and English language ability, the odds of holding a skilled occupation go down the longer a Mexican man remains in the United States. As with Mexican men, a skilled occupation is achieved by Mexican women through secondary schooling and language ability, whereas among Moroccan women a skilled occupation is achieved through secondary schooling and social capital.

Although different factors may contribute to skilled occupations in the two immigrant groups, the likelihood of attaining a skilled occupational attainment is in fact not that different between the two groups. With the exception of women, where the intercept for Mexicans in the United States $(b=-4.736)$ is much higher than that for Moroccans in Spain $(b=-7.128)$, the full sample and the male sample's intercepts are not significantly different across the two migrant groups. In other words, although the paths to a skilled occupation may differ between the two countries, the actual odds of skilled occupational achievement are not that different from one another.

\section{Wage Determination in Binational Perspective}

A final test of economic adaptation is the hourly wage that immigrants earn in the host country. Table 4 presents OLS regression estimates showing how different independent variables affect earnings controlling for occupational skill. Using the log of wages as the dependent variable enables us to interpret coefficients as indicating the percentage difference in wages associated with unit changes in the covariates. We immediately observe that female migrants incur an economic penalty in both countries, though the penalty is significant larger for Mexican women in the United States than for Moroccan women in Spain. Whereas the average Mexican woman earns 33\% less than a Mexican man in the U.S. labor market, other things being equal, the average Moroccan woman earns just 18\% less than a Moroccan man in the Spanish labor market.

Among the remaining demographic factors, age is positively associated with wages in both countries, but the returns to age are larger for Mexicans in the United States (4.4\% per year) than for Moroccans in Spain (2.5\% per year). Wages do not appear to be strongly affected by social capital, but are strongly determined by education, experience and occupational skill. Secondary schooling yields an $8 \%$ wage premium among Moroccans and a $10 \%$ premium 
among Mexicans (though the latter effect is not statistically significant), whereas attaining a skilled occupation is associated with a $20 \%$ wage premium among Mexicans but only an 11\% premium among Moroccans. By contrast, host country experience pays larger dividends for Moroccans than Mexicans, raising their wages by $1.2 \%$ per year compared with just $0.7 \%$ per year for Mexicans. Despite these differences of magnitude among the covariates, the model intercepts for Mexicans $(b=1.141)$ and Moroccans $(b=1.144)$ are nearly identical, suggesting that the previously observed wage differentials derive from variables included in the model and not fixed effects between countries.

With stronger returns to age, education and occupational skill, and only modestly lower returns to host country experience, the barriers to economic integration would appear to be lower for Mexicans compared with Moroccans, a conclusion that is reinforced by the much larger share of variance explained by the Mexican model $\left(R^{2}=0.41\right)$ than the Moroccan model $\left(R^{2}=0.15\right)$. Turning to the gender-specific models, however, we see that this conclusion holds more for men than women. Among Moroccan males in Spain, only two variables are significant in predicting wages - age and host country experience- and the $\mathrm{R}^{2}$ is just 0.09 , whereas among Mexican males in the United States five variables are significant and the $\mathrm{R}^{2}$ is 0.19 . Moreover, although the effect of age is not significant in statistical terms, in substantive terms it is equivalent to that shown in the Moroccan model. In addition, Mexican male wages are increased by the presence of children ( $2.9 \%$ per child), host country experience ( $0.6 \%$ per year), English language ability ( $11 \%$ per unit), presence of a spouse $(21 \%)$, and holding a skilled occupation (17\%). Holding these effects constant, the substantively equivalent intercepts suggest that male Moroccans in Spain and Mexican males in the United States earn essentially the same wages.

Among women, the contrast in wage achievement is not so great, as the equations yield similar R-squares (0.29 for Moroccans and 0.27 for Mexicans), even though the leading determinants are somewhat different. For Moroccan women, the key determinants of earnings are education, experience and skill, with secondary schooling yielding a $26 \%$ wage premium, each year of host country experience raising wages by $1.5 \%$, and attainment of a skilled occupation raising wages by $26 \%$. The same factors are important in determining the wages earned by Mexican women in the United States, though the effects are generally smaller: secondary schooling produces just a $9 \%$ wage premium, each year of experience raises wages by only $0.8 \%$, and attainment of a skilled occupation brings only a $22 \%$ wage gain. In addition to these effects, the wages of Mexican women are also boosted by age ( $4.2 \%$ per year) and language ability (12\% per unit). Thus, although females incur a larger wage penalty in the United States than in Spain (see the difference between the female coefficients in the left-hand equations and the different intercepts in the right-hand equations), to the extent that Mexican women in the United States can bring the additional resources of life experience (age) and host country language ability to bear, they can earn comparable wages as Moroccan women in Spain. 


\section{Summary and Conclusion}

Our results do not offer a firm conclusion about which reception country better integrates frontier labor force migrants, Spain or the United States. Nonetheless, the analysis offers some clues about which determinants operate more effectively in each setting. We began the analysis with a comparison of economic outcomes and socio-demographic variables between Moroccans in Spain and Mexicans in the United States. Although more differences than similarities were found in uncontrolled comparisons, multivariate analysis indicated more similarities between Moroccan and Mexican migrants than anticipated. As evidenced by similar intercepts for wages and the probability of skilled occupational attainment, most of the economic differences observed in the raw comparisons were explained by the human and social capital variables included in the models.

Differences in economic adaptation for the two migrant groups are thus portrayed less in the ultimate outcome than in the paths by which employment, skilled occupations, and higher wages are attained. In predicting employment among those in the labor market, many of the factors usually posited to influence economic outcomes (i.e., age, education, language ability, and social ties) had little effect in explaining employment differences between the two countries, but which factors were insignificant varied with context. Among Moroccan women in Spain, the likelihood of employment rose with language ability and time spent in the host country, whereas among Mexican women in the United States, the odds of employment rose with time spent in the host country, age and education.

Based solely on the probability of employment, it may appear that Mexicans in the United States economically integrate more successfully than Moroccans in Spain. However, an analysis of the probability of skilled occupational attainment yields a more complex picture. While education has almost equal effects in predicting attainment of a skilled job in both immigrant groups, increased host country experience favors Moroccans over Mexicans whereas language experience favors Mexicans over Moroccans. When considering the effect of the same covariates on wages, however, the reverse picture emerges. It is Moroccans who gain higher wages with education and host country experience, whereas language ability generally benefits Mexican immigrants in the United States more.

Given these alternative stories of economic adaptation, it remains a challenge to assess whether a greater exclusion is occurring for Moroccans in Spain or Mexicans in the United States. When viewed through economic outcomes such as employment, it appears labor discrimination against Moroccans in Spain is more prominent than discrimination against Mexicans in the United States; but once a job has been procured, patterns of occupational mobility and wage attainment yield no clear conclusion about which country houses the more hostile context of reception. This nuanced picture could reflect different selection effects in predicting labor migration from Morocco and Mexico. 
Although there are many geographic similarities between the two nations, Morocco is not as economically advanced as Spain relative to Mexico and the United States. Further, the Morocco-to-Spain migration flow is not as mature as the Mexico-to-U.S. migration stream. Following the militarization of the Mexico-U.S. border during the 1990s, migrants from Mexico have evolved into a settled pattern of family migration, whereas migrants from Morocco are typically young, single or married men who engage in seasonal migration to support their extended family in Morocco. Given these differences in migratory peaks for the two host countries, we would expect the paths of occupational attainment and determinants of wages to be different.

Naturally, our analysis has important shortcomings. Economic adaptation and social mobility are long-term processes that unfold over time, and in this study we are forced to rely on cross-sectional samples and synthetic cohorts based on time spent in the host country. Further analysis using additional waves of the NIS or other data sources in Spain are needed to provide more conclusive results in comparing outcomes between Mexicans and Moroccans. In addition, the different sampling frames for the two surveys might condition results. For example, many of the newly legalized Mexican migrants were already living in the United States, producing a broader range of language ability that yield a larger empirical payoff. Relative to the NIS sample in the United States, such long-term residents may be underrepresented in the ENI sample in Spain. In this case, we would expect country experience rather than language ability to be a better predictor of higher wages.

This analysis should thus be considered a first step in the comparative study of these two groups within two very different receiving societies. Despite its inherent shortcomings, we hope our study provides a basis for future comparative research not only between Spain and the United States, but between Europe and North America more generally as well as for other outcomes besides wages and occupational status. Economic integration is but one dimension of a much broader process of assimilation that incorporates diverse social, cultural, and political outcomes.

\section{References}

Alba, Richard (2005). "Bright vs. Blurred Boundaries: Second Generation Assimilation and Exclusion in France, Germany, and the United States". Ethnic and Racial Studies, 28 (1), 20-49.

ARANGo, Joaquín and JaCHimowicz, Maia (2005). "Regularizing Immigrants in Spain: A New Approach". Migration Information Source: Fresh Thought, Authoritative Data, Global Reach. Washington, DC: Migration Policy Institute. Accessed online at http://www.migrationinformation.org/Feature/display.cfm?ID=331

BAsoK, Tanya (2002). Tortillas and Tomatoes: Transmigrant Mexican Harvesters in Canada. Montreal and Kingston: McGill-Queen's University Press.

- (2003). "Mexican Seasonal Migration to Canada and Development: A Community-Based comparison". International Migration, 41 (2), 3-26. 
Bodega, Isabel; Cebrian, Juan A ; Franchini, Teresa; Lora-Tamayo, Gloria and Martin-Lou, Asunción (1995). "Recent Migrations from Morocco to Spain." International Migration Review, 34 (3), 800-819.

Calavita, Kitty (1998). "Immigration, Law, and Marginalization in a Global Economy: Notes from Spain”. Law and Society Review, 32 (3), 529-66.

de HaAs, Hein (2005a). "Morocco's Migration Transition: Trends, Determinants, and Future Scenarios”. Global Migration Perspectives, No. 208. Geneva: Global Commission on International Migration.

- (2005b). "Morocco: From Emigration Country to Africa’s Migration Passage to Europe". Migration Information Source: Fresh Thought, Authoritative Data, Global Reach. Washington, DC: Migration Policy Institute. Accessed online at http:// www.migrationinformation.org/Profiles/display.cfm?ID=339

- (2007). "Morocco's Migration Experience: A Transitional Perspective." International Migration, 45 (4), 39-69.

de Haas, Hein and Fokkema, Tinneke (2009). "Transnational Return and Pendulum Migration Strategies of Moroccan Migrants: Intra-Household Tensions and Conflicts of Interest". Paper presented at the XXVI International Population Conference, International Union for the Scientific Study of Population, Marrakech, 1 October 2009.

Donato, Katharine M.; Durand, Jorge; Hiskey, John and Massey, Douglas S. (2010). "Migration in the Americas: Mexico and Latin America in Comparative Context". Annals of the American Academy of Political and Social Science, 630, 6-19.

Durand, Jorge and Massey, Douglas S. (1992). "Mexican Migration to the United States: A Critical Review". Latin American Research Review, 27 (2), 3-43.

Durand, Jorge; Massey, Douglas S. and Parrado, Emilio A. (1999). "The New Era of Mexican Migration to the United States". Journal of American History, 86 (2), 518-536.

Gregorio Gil, Carmen and Ramírez Fernández, Angeles (2000). “¿En España es diferente...? Mujeres Inmigrantes Dominicanas y Morroquís”. Papers: Revista de Sociología, 60, 257-273.

Hennebry, Jenna L. (2008). "Bienvenidos a Canadá? Globalization and the Migration Industry Surrounding Temporary Agricultural Migration in Canada”. Canadian Studies in Population, 35 (2), 339-356.

Jasso, G.; Massey, D.; Rosenzweig, M. and Smith, J. (forthcoming). “The U.S. New Immigrant Survey: Overview and Preliminary Results Based on the New-Immigrant Cohorts of 1996 and 2003”. In: Morgan, B. and Nicholson, B. (eds.), Longitudinal Surveys and Cross-Cultural Survey Design. London: UK Immigration Research and Statistics Service.

KopinaK, Kathryn and Soriano Miras, Rosa María (2009). "Viviencias Transnacionales en el Estudio de las Migraciones Internacionales: Mexicanos en EE.UU. y Maroquíes en España." Unpublished paper. Centre for Research on Latin America and the Caribbean, York University/Department of Sociology, University of Granada.

Lopez, Maria Pabon (2007). “Immigration Law Spanish-Style: A Study of Spain’s Normalization of Undocumented Workers”. Georgetown Immigration Law Journal, 21, 571-594

Massey, Douglas S. (1988). "International Migration and Economic Development in Comparative Perspective". Population and Development Review, 14 (3), 383-414. 
- (2008). "La Racialización de Mexicanos en Los Estados Unidos: Estratificación Social en la Teoría y la Práctica”. Migración y Desarrollo, 10, 65-95.

Massey, Douglas S. (2009). "Racial Formation in Theory and Practice: The Case of Mexicans in the United States". Race and Social Problems, 1 (1), 12-26.

- (2010). "The Past and Future of Mexico-U.S. Migration". In: Overmyer-VelazQuez, Mark (ed.), Beyond the Border: The History of Mexico-U.S. Migration. New York: Oxford University Press.

Massey, Douglas S.; Alarcón, Rafael; Durand, Jorge and González, Humberto (1987). Return to Aztlan: the Social Process of International Migration from Western Mexico. Berkeley (CA): University of California Press.

Massey, Douglas S.; Arango, Joaquín; Hugo, Graeme; Kouaouci, Ali; Pellegrino, Adela and TAYLOR, J. Edward (1994). "An Evaluation of International Migration Theory: The North American Case". Population and Development Review, 20 (4), 699-752.

Massey, Douglas S.; Durand, Jorge and Malone, Nolan J. (2002). Beyond Smoke and Mirrors: Mexican Immigration in an Age of Economic Integration. New York: Russell Sage Foundation.

Massey, Douglas S.; Durand, Jorge and Pren, Karen (2009). "Nuevos Escenarios de la Migración México-Estados Unidos: Las Consecuencias de la Guerra Antiinmigrante." Papeles de Población, 61, 101-128.

Massey, Douglas S. and Malone, Nolan J. (2003). "Pathways to Legalization”. Population Research and Policy Review, 21 (6), 473-504

Massey, Douglas S. and Sánchez R., Magaly (2010). Brokered Boundaries: Creating Immigrant Identity in Anti-Immigrant Times. New York: Russell Sage Foundation.

Migration News (1998). "Illegal Immigration: Spain/Morocco”. Migration News 4 (4), 1.

Relaño Pastor, Ana María and Soriano Miras, Rosa María (2006). "La Vivencia del Idioma en Mujeres Migrantes: Mexicanas en Estados Unidos y Marroquíes en España”. Migraciones Internacionales, 3 (4), 85-117.

Reniers, Georges (1999). "On the History and Selectivity of Turkish and Moroccan Migration to Belgium”. International Migration, 37 (4), 679-713.

Roque, María Angels (1994). "Percepciones Controvertidas: Migración Marroquí en Cataluña”. Papers: Revista de Sociología, 43, 79-87.

Salih, Ruba (2001). "Moroccan Migrant Women: Transtionalism, Nation-States, and Gender". Journal of Ethnic and Migration Studies, 27 (4), 655-671.

Singer, Audrey and Massey, Douglas S. (1998). "The Social Process of Undocumented Border

Crossing". International Migration Review, 32 (3), 561-92.

Skeldon, Ronald (1997). Migration and Development: A Global Perspective. London: Longman Publishing Group.

Soriano Miras, Rosa María (2006). "La Inmigración Femenina Marroquí y su Asentamiento en España: Un Estudio des la Grounded Theory”. Revista Internacional de Sociología, 64 (43), 169-191.

- (2008). "Inmigrantes e Identidad Social: Similitudes y Diferencias en el Proyecto Migratorio de Mexicanas a EE.UU. y Mujeres Marroquíes a España”. Migraciones, $23,117-150$.

United Nations (2009). Moroccan Migration to Spain. Santo Domingo: International Training Institute for the Advancement of Women. 
U.S. Central Intelligence Agency. CIA World Factbook. Langley (VA): U.S. Central Intelligence Agency. https://www.cia.gov/library/publications/the-worldfactbook/

White, Gregory (1999). "Encouraging Unwanted Immigration: A Political Economy of Europe's Efforts to Discourage North African Immigration". Third World Quarterly, 20 (4), 839-854.

- (2001). "Risking the Strait: Moroccan Labor Migration to Spain". Middle East Report, 31 (218), 26-29. 